\title{
IMPROVEMENTS IN THE CAPABILITY PROFILE OF 3-D PRINTING: AN UPDATE
}

\author{
D.M. Dimitrov ${ }^{1 *} \&$ N. de Beer ${ }^{2}$ \\ Department of Industrial Engineering \\ Stellenbosch University, South Africa \\ 1dimitrov@sun.ac.za
}

\begin{abstract}
Knowledge about the capabilities of a production system is an important issue. The threedimensional (3-D) printing (drop-on-bed) process has become a well-established Additive Manufacturing (AM) technology. Initially intended for use mainly as a concept modeller, its scope of application has expanded to include, among others, fit and functional models, pattern-making for casting and moulding processes, rapid tooling, and medical and architectural models. This growth in applications has stimulated a reciprocal improvement in available materials and the technological capabilities of 3-D printing, such as accuracy, strength and elongation, surface finish, build time, and cost. These factors are of significance to users who want to control their processes better and to designers who want to define their expectations and determine their requirements. Thus this paper aims to provide a technical update, highlighting the influence level of different factors on a system's capabilities. This paper uses the example of the ZPrinter 310 system from the Z Corporation, applies appropriate statistical techniques, and takes into consideration the latest material and machine developments, in order to report on the current improvements of the capability profile of this important process.
\end{abstract}

\section{OPSOMMING}

Kennis oor die vermoëns van 'n produksie sisteem is ' $n$ baie belangrike kwessie. Die 3-D druk proses het ' $n$ goed gevestigde additiewe vervaardigingstegnologie geraak. Aanvanklik was die hoof doel hiervan om konsepte te modelleer, maar nou is die toepassing uitgebrei om, onder andere, pas en funksionele modelle, patroon vervaardiging van giet prosesse, snel vervaardiging van gereedskap, mediese modelle, en argitektoniese modelle in te sluit. Hierdie groei in aantal toepassings het ' $n$ wedersydse verbetering in die beskikbaarheid so wel as tegnologiese vermoëns van 3-D druk soos akkuraatheid, sterkte, verlenging, afwerking, bou tyd, en kostes tot gevolg gehad. Hierdie faktore is baie belangrik vir gebruikers om beter beheer toe te pas oor hul prosesse, en vir ontwerpers om hul verwagtinge te definieer en om vereistes te bepaal. Hierdie artikel het ten doel om ' $n$ tegniese opdatering te gee van wat die invloed van verskillende faktore op 'n sisteem se vermoëns is. Deur gebruik te maak van die ZPrinter 310 sisteem van Z-Corporation as voorbeeld, en met die toepassing van gepaste statistiese tegnieke en inagneming van onlangse materiaal- en masjienontwikkelinge, word die nuutste verbeteringe van die vermoënsprofiel vir 3-D druk tegnologie bespreek.

\footnotetext{
2 Post-doctoral student at the Department of Industrial Engineering, Stellenbosch University

* Corresponding author
} 


\section{$1 \quad$ INTRODUCTION}

Additive Manufacturing (AM) technologies have expanded vastly over the last 20 years of their history. Originally seen as only suitable for Rapid Prototyping (RP), these processes are not exclusively used for that purpose any longer. With the advent of new materials, along with new processes, each technology has contributed to the diversity found in the different fields of application. In order to improve current processes and technologies, and even future processes and technologies, it is critical to understand exactly what the capability of each technology is.

During the last 15 years, intensive research efforts have focused primarily on the so-called high-end additive processes and, above all, on the Stereolithography (SLA) and Selective Laser Sintering/ Selective Laser Melting (SLS/ SLM) technologies. This research has explored various issues that relate mostly to process control and material property improvement. In recent years, three-dimensional (3-D) printing has come to the fore as a very competitive process in terms of cost and speed, and sales of related equipment have increased significantly compared with other AM machines. Figure 1 shows the number of sales of 3-D printers from 2005 to 2010, extrapolated from [1]. These devices were developed, and are still seen, mostly as a 'concept modeller'. However, with the larger selection of materials available today and the wide variety of post-treatment procedures, the scope for this technology has grown quickly - far beyond the original idea of generating design iterations or producing pattern equipment for various casting processes directly from a CAD file. Therefore it is appropriate to assess and provide an update on the current improvements that this technology has been able to achieve.

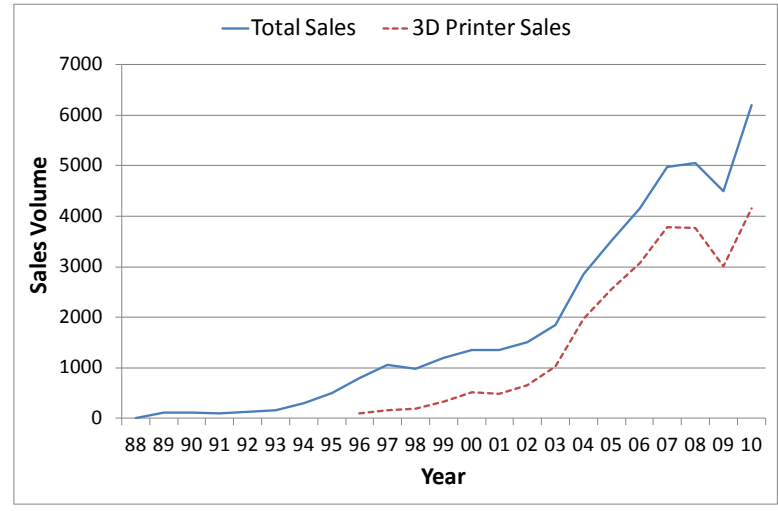

Figure 1: Growth of global AM equipment sales [1]

\section{3-D PRINTING: DEFINITION AND CLASSIFICATION}

A large variety of 3-D printing techniques have been introduced into the AM industry over the past 15 years. Depending on the method used, a thermal, polymer, or physical phase change takes place.

Table 1 shows the different deposition techniques that link up to the different technologies that make use of them.

Based on the variety of applications that use the 3-D printing process, the following classification of 3-D printing techniques is derived (Figure 2). 
Table 1: Summary of processes and corresponding technologies

\begin{tabular}{|l|ll|}
\hline Aimed deposition process & \multicolumn{1}{c|}{ Technology } \\
\hline Drop-on-drop deposition & $\bullet$ & $\begin{array}{l}\text { 3-D plotting } \\
\text { Multi-jet modelling }\end{array}$ \\
\hline Drop-on-powder deposition & $\bullet$ & 3-D printing \\
\hline Continuous deposition & $\bullet$ & Fused deposition modelling \\
\hline
\end{tabular}

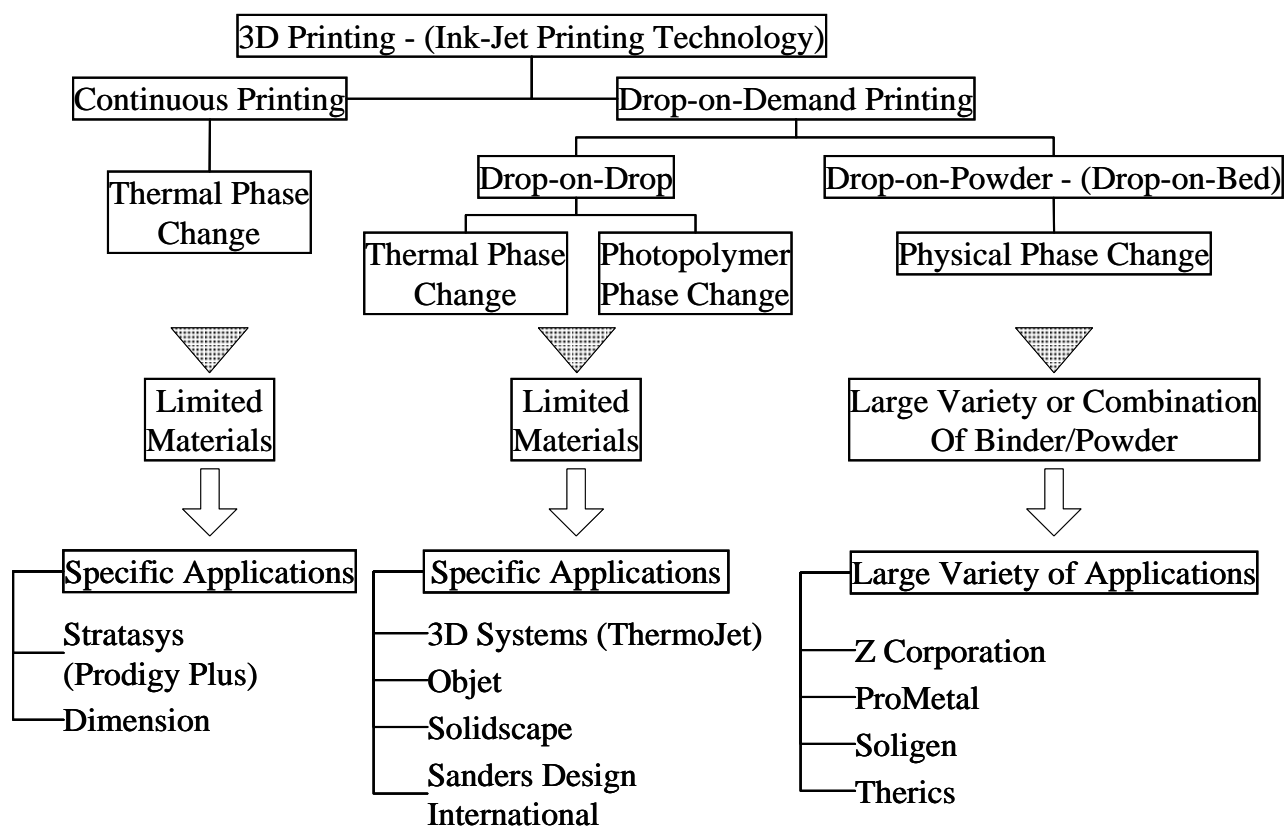

Figure 2: Classification structure of 3-D printing techniques used in AM applications

From the above diagram, the similarities of the 'drop-on-drop' (DoD) and the 'continuous printing' techniques can be seen, where the 'printable fluid' and the 'building substance' are one and the same material. This means that the building material has to meet two requirements: the first relates to the fluid's printability and the second relates to the purpose of building the model (i.e., the intended application). The need to fulfil this set of requirements puts substantial limits on the range of materials suitable for a particular application. In contrast, the 'drop-on-bed' (DoB) (powder) version distributes to two different substances the responsibility to meet the requirements. In fact, almost every material can be brought to a powder state, which is also the starting point of the SLS process. With this in mind, the task to bring a material in the state to be processed in a 3-D printing device changes to a task to find a suitable binding liquid. This scenario predetermines a much larger variety of suitable combinations, and thus a much larger application range. The possibility of using infiltrating agents in the next stage of the model's manufacturing process further extends the variety of applications [2]. This fact is illustrated by the conceptual diagram in Figure 3, which depicts the areas of application in relation to the quantity of machine units sold (based on [1]) for each of these 3-D printing techniques. Printer machines that make use of the 'continuous printing' technique have far exceeded (by almost three times) the sales volumes of those that make use of the DoD or the DoB techniques. Important to note here is that printers using the DoB technique span over a wider range of applications. 


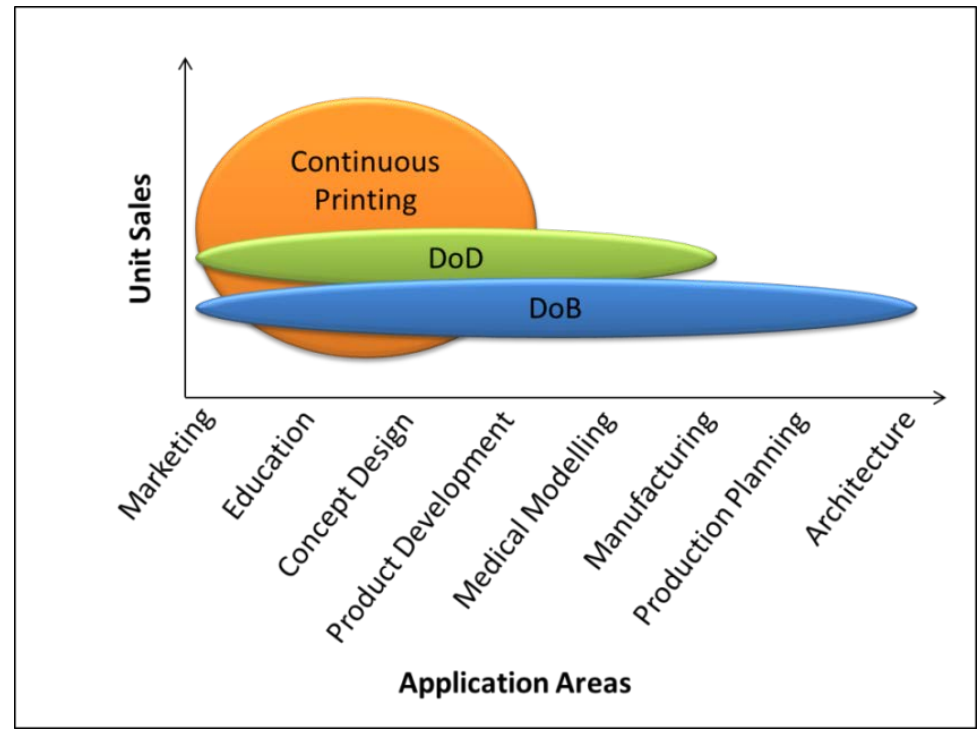

Figure 3: Conceptual depiction of machine unit sales and areas of application

\section{ADDITIVE MANUFACTURING PROGRESS DEVELOPMENT}

Since the commercialisation of the first 3-D printer system, research endeavours have been made to improve various areas of its system hardware, software, or materials. Other system developers, such as 3-D Systems with their SLA process, have had similar experiences in attempting to improve their overall product performance. This has led to the development of an aid, aptly referred to as 'the wheel of progress' (Figure 4), for understanding the process improvement. In this illustration, the hill to be climbed is the increasing performance of AM systems. The wheel, which represents the hardware, software, building process, and materials used to make parts, can move up the hill if sufficient driving force is applied.

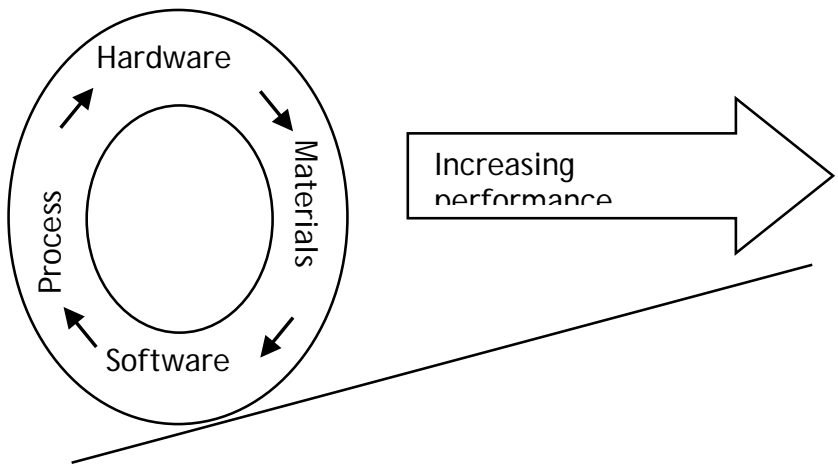

Figure 4: 'The wheel of progress' [3]

Insight gained by using this model indicates that once a technique is configured with all four components in place, it soon becomes clear that one of the components is a limiting factor that impedes advancement up the 'hill of progress'. Continued research, development, and engineering attention to the appropriate topic eventually yields an improved capability of that component, and allows the wheel to travel a little further uphill. But no sooner has that limitation been overcome than another takes its place, and so it continues. Improved hardware requires enhanced software and better processing techniques, after which the materials will require upgrading. A clear example of this 
analogy in action is discussed below, where it is shown how an improvement in materials and software leads to an improvement in process.

\section{CAPABILITY PROFILE UPDATE}

\subsection{Accuracy}

One of the important factors that define the capability profile of the 3-D printing process is the issue of accuracy. Indeed, for a large variety of applications - conceptual modelling, design aids, and anatomical modelling, to mention a few - the question of accuracy is irrelevant. However, for some of the most important applications, such as fit and function tests or pattern-making for a number of moulding and forming processes, this question of (guaranteed) accuracy is of prime importance. Accuracy can be defined as a generic concept of exactness related to the closeness of agreement between the average of one or more test results and a reference value. The results from previous studies $[2,4,5]$ were recently updated by repeating some of the experiments for the latest zp150 material that was infiltrated with cyanoacrylate. These tests were conducted using a Spectrum Z510 machine. Nine benchmark cubes were produced with various nominal dimensions, as shown in Figure 5.

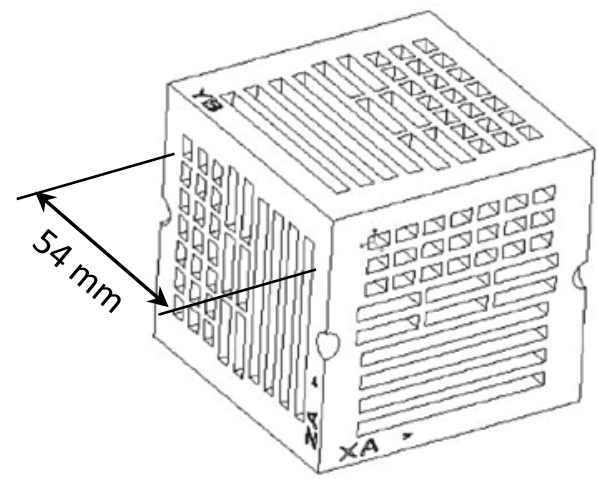

Figure 5: Benchmark part used in this study

Mean errors were calculated from the measurements of nominal dimensions (Figure 6). The zp150 material exhibits a significant improvement in part quality and accuracy over previous material and infiltration combinations [2]. The average error values fluctuate in the order of $\pm 0.1 \mathrm{~mm}(\sigma=0.08 \mathrm{~mm})$. Values for the Y-build direction appear to perform marginally better than the $X$ - and Z-build. In addition to measuring nominal dimensions, the influence of the location in the build volume of the printer on part accuracy was also investigated and compared with previous studies [2]. For this purpose, nine parts were spaced equally in the build volume (one in each corner and one in the centre), and a comparison was made between the $18 \mathrm{~mm}$ nominal dimensions of the same build directions, but in their different build locations. On each cube, a total of 108 representative measurements for each build direction were investigated. The results of the measurements are shown in Figure 7 below.

Measured values in the Y-build direction appear most stable. The reason for this may be associated with the fact that the action of spreading the powder takes place in the $X$ direction. The Y-build direction may not be affected by this action.

A more concerning observation, however, is seen in the disparities between measured values in the Z-build direction for the zp102 powder (discontinued in October 2005). The circled points in the bottom graph refer to measures taken on the cubes that were on the top and centre layer of the build volume. Their values are distinctly different in magnitude from cubes built in the bottom layer. The bottom cubes display much higher accuracy with lower dispersion. From these observations, it follows that the significant influences to part accuracy in the Z-build direction can be attributed to a combination between powder and 
binder weight, and the fact that unbound powder does not lend enough support to parts built higher up in the build volume. As binder liquid is added to the powder in the top section, the powder becomes heavier and starts to 'sink' into the excess powder. Therefore, the claim that the free powder will provide sufficient support during the building process could not be confirmed. This means, for example, that overhangs and other delicate shape elements must be built by creating a suitable (and removable) support structure. This problem was realised recently by the equipment manufacturer ZCorporation, which refers to this phenomenon as 'squash', which is similar to the working of quicksand. This led to the development of specialised software features that provide an aid for creating this kind of additional support. The subsequent improvement is clearly seen in the stable measurements recorded for the zp150 powder.

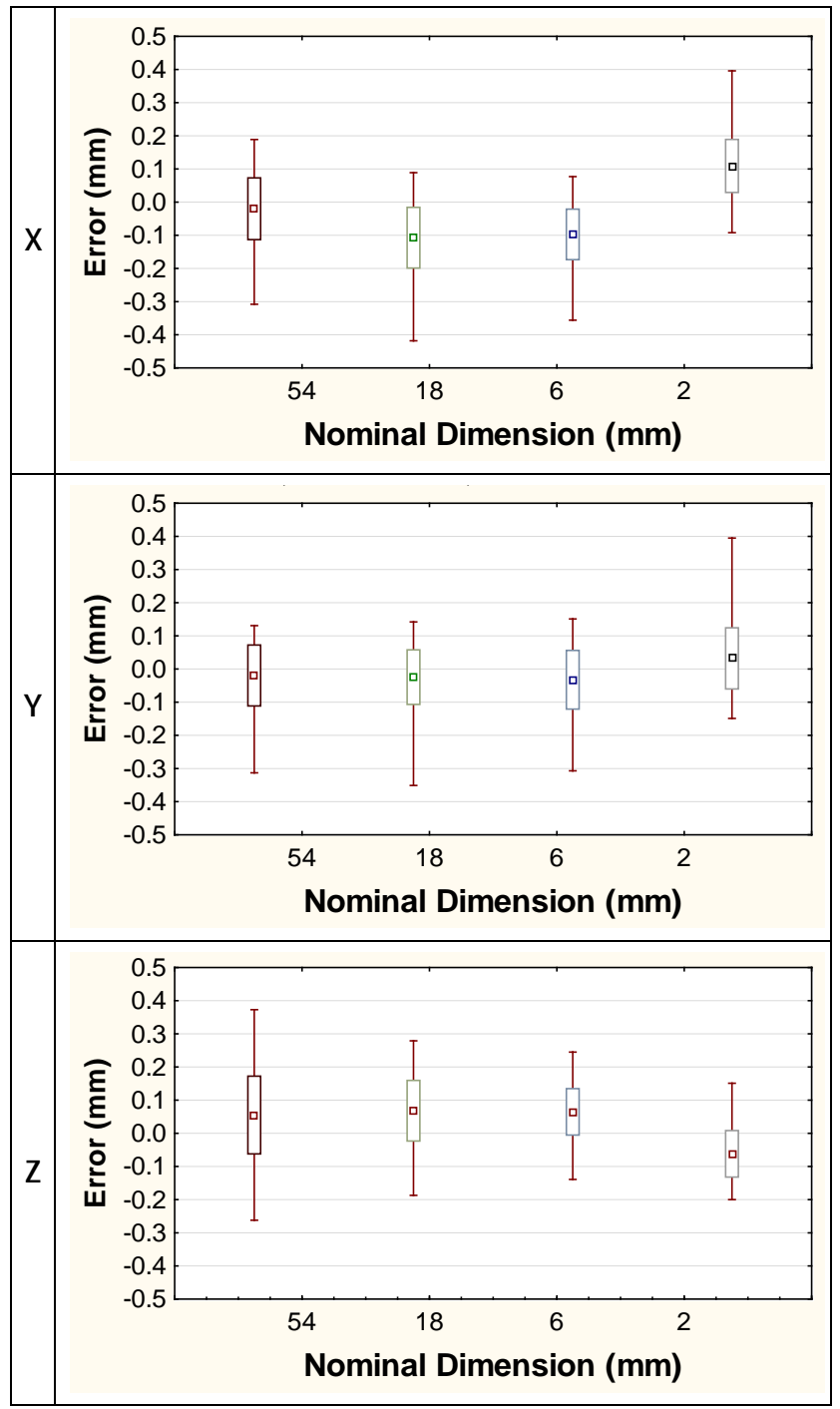

Figure 6: Box plot of average errors per build direction and nominal dimension for zp150 powder (Box: Mean \pm SD; Whisker: Min-Max) 
KEY: LFB = Left Front Bottom; RFB = Right Front Bottom; LBB = Left Back Bottom; RBB = Right Back Bottom; CEN = Centre; LFT = Left Front Top; RFT = Right Front Top; LBT $=$ Left Back Top; RBT = Right Back Top

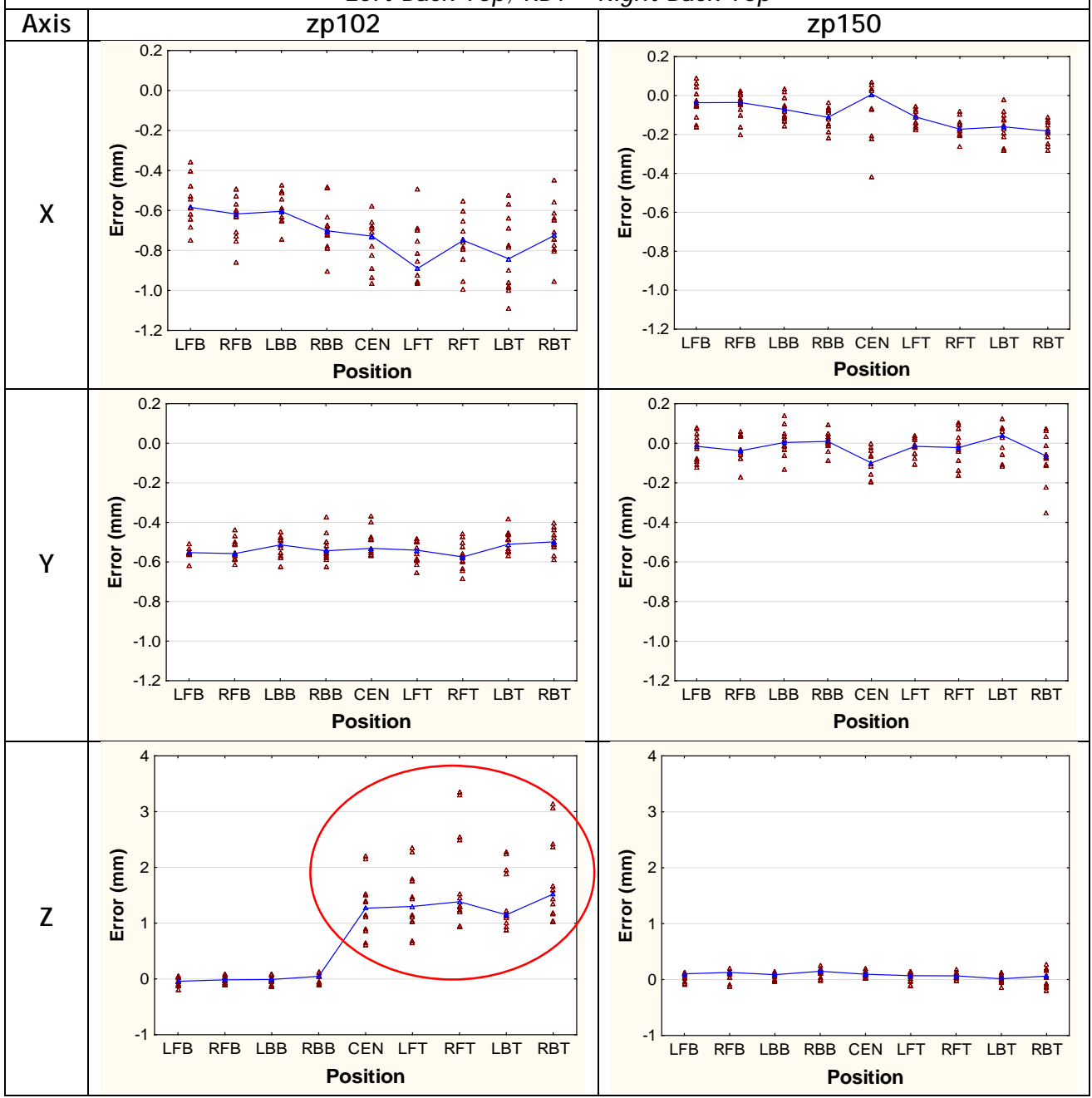

Figure 7: Error distributions of $\mathbf{1 8} \mathbf{~ m m}$ nominal dimensions at different build locations per material

\subsection{Surface roughness}

Surface roughness measures $\left(R_{a}\right)$ were also taken on each of the parts built. Eight measurements were taken on each cube, and mean values were calculated for each build direction. The results are shown in Figure 8 , in combination with historical results for zp102 powder [2]. It appears that even though zp150 material has exhibited improvements in part accuracy, the surface roughness has not followed suit. As before, the Y-build direction still shows the best results, while the Z-direction predictably has the poorest surface quality due to the build layers. 


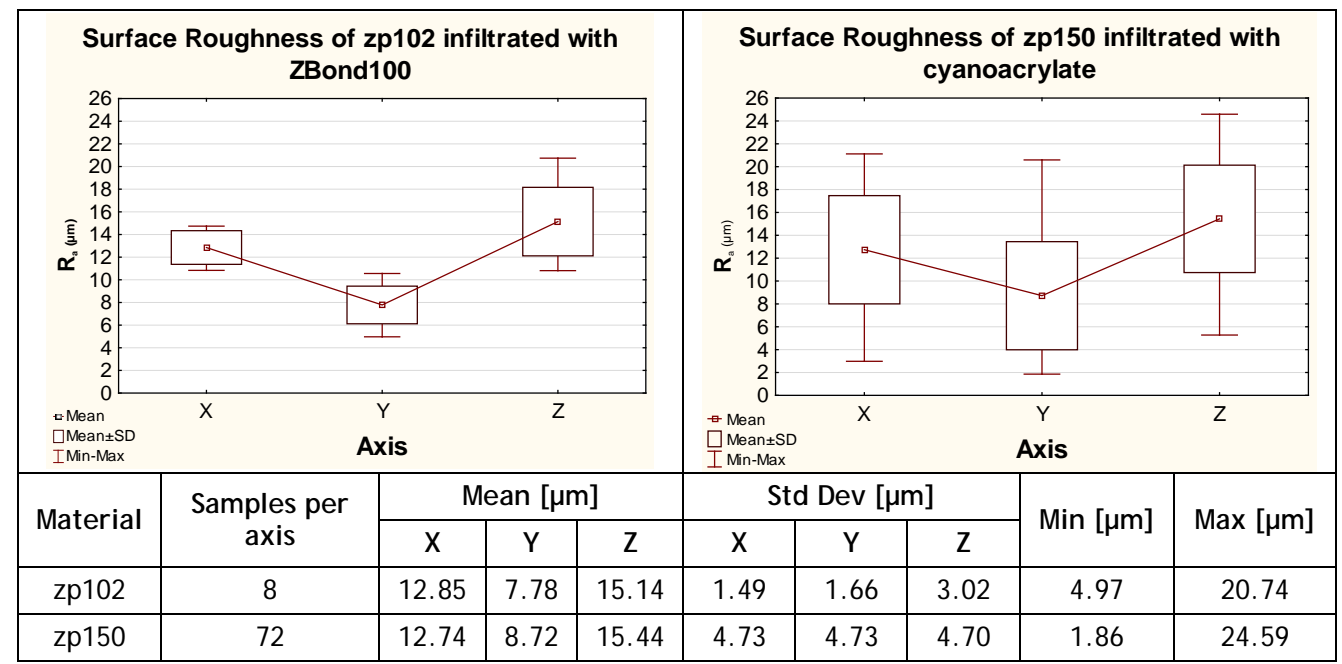

Figure 8: Surface roughness values per material

\subsection{Build time and cost}

The time required to build a part on a 3-D printer will always be of great interest. A basic cost model for 3-D printing processes is provided by [6].

Table 2 shows a breakdown of the time (infiltration time not included) associated with the different activities of the 3-D printing process, for each of the materials. The times relate to the 3-D printing of five benchmark cubes per material - a total printed volume of 681.1 $\mathrm{cm}^{3}$ per print session. The zp102 parts were produced on the ZPrinter 310 system, while the zp150 parts were produced using the Z510 Spectrum machine. This data clearly shows a vast improvement in building speed.

Table 2: Build and processing times associated with each material

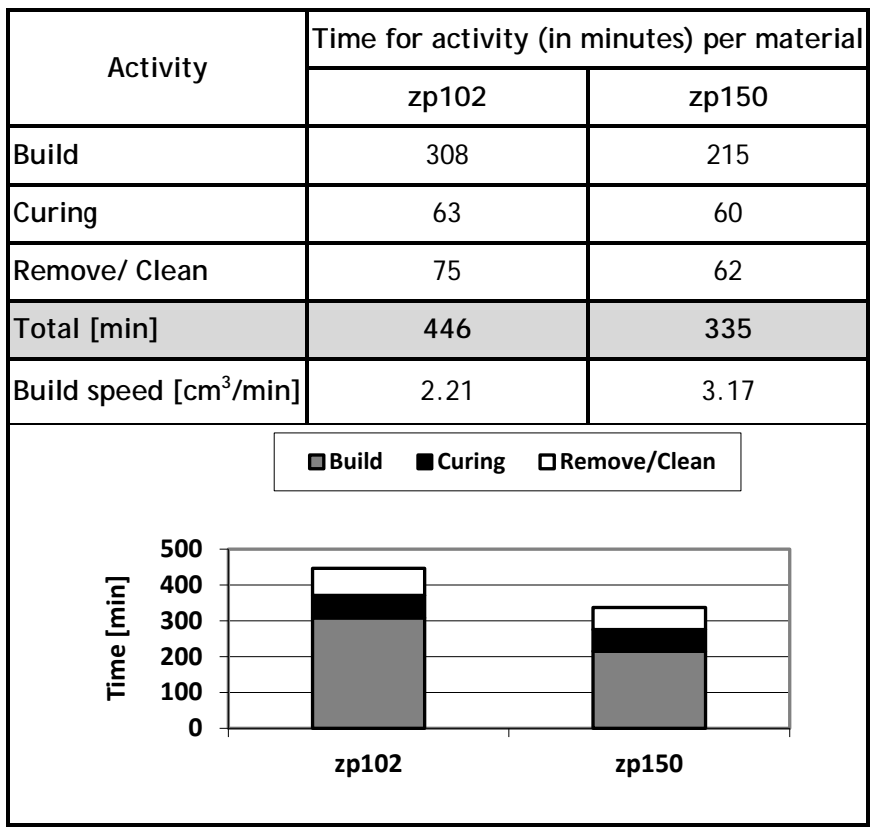




\section{APPLICATIONS OF 3-D PRINTING}

Contrary to popular opinion in previous years, 3-D printing processes are currently used in a wide variety of applications. By considering some of these applications, it becomes clear that because of the improvements in hardware, materials, and software, as shown in the 'wheel of progress', new applications became possible with improved 3-D printing processes.

\subsection{Design and proof of concept}

Proof of concept was the original intention of 3-D printing, and was therefore one of its main strengths. The comparatively low capital cost of the systems and the fast printing times are ideally suited for physical models to be quickly created during any design stage. These physical models enhance communication, especially between engineers and nonengineers, and are an additional tool that can be used to minimise design errors. One such example is a case in which 3-D printing aided the design of the core system of a marine engine gearbox by allowing a half-scale mock-up of the pattern and core system (Figure 9). This facilitated discussion and planning of the core system, ensuring that sufficient support was provided for all cores, checking the wall thickness, and deciding on the core layout and the number of required cores. This process of bringing designers, pattern makers, and foundry personnel together as a coherent engineering design team is invaluable.

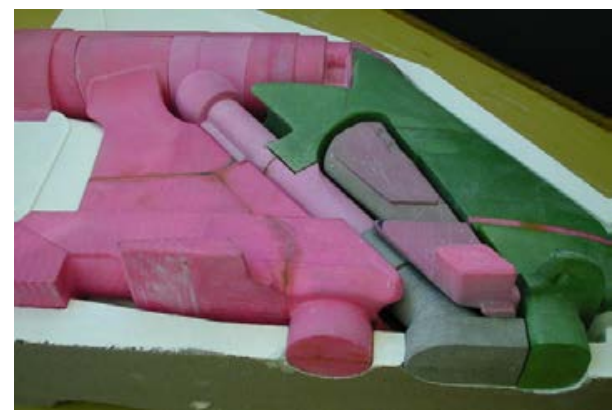

Figure 9: Core layout development

Furthermore, the ability of a 3-D printer now to print in colour can add a lot of value in design communication. Colours can be used to represent non-geometrical information that cannot necessarily be painted on afterwards - e.g., the results of a stress analysis, draft angles, highlighting landmarks, etc. Colours can also simply be used to represent the final printing and/ or painting of the component. No matter how it is used, it is a cost-efficient means of adding value to prototypes early in the design phase. Other studies $[7,8]$ on the quality and longevity of colour found some discrepancies in the reproduction of colours, and also found that post-treatment and infiltrant material had an influence. The newer ZPrinter 650 machine, with a dedicated black channel, produced better results than the Z510 machine, again showing how new hardware has advanced the 'wheel of progress'.

\subsection{Market research}

The comparatively low cost of a 3-D printer's parts also makes the process ideal for developing models for market research and other marketing purposes. Product developers can have the advantage of a physical prototype, albeit not necessarily a functional one, when taking their designs to potential customers. This gives the customer a much more realistic impression of the product long before committing to expensive manufacturing processes.

The prototype of a mop dryer (Figure 10) was made so that national retailers could see the product before committing to its manufacture with expensive injection mould tooling. Although the part $(312 \times 194 \times 98 \mathrm{~mm})$ is much larger than the $3-D$ printer's build volume, it was built in sections that were then glued together after printing, in less than 48 hours. 


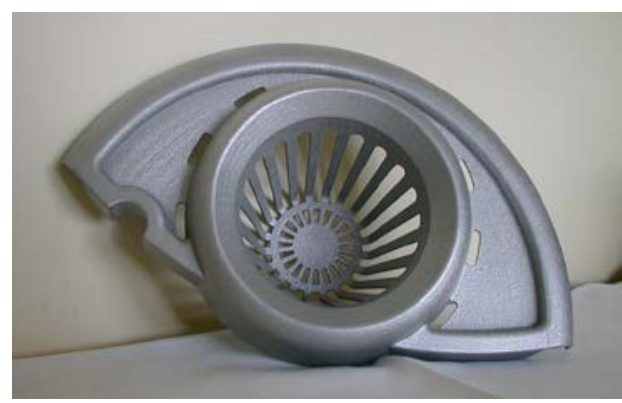

Figure 10: Prototype of a mop dryer (courtesy of USABCO)

\subsection{Functional prototypes}

The purpose of these models is to test the fitment in a larger assembly or to test one or more of the functions of a product. For functional testing, some of the prototype's material properties - its yield strength, hardness, elasticity, water resistance, heat resistance, etc. need to closely match the end-use material. The accuracy of the prototype must also be within acceptable limits. Where 3-D printing materials and process limitations preclude the use of these prototypes for this purpose, some secondary processes can be employed. An example is shown in Figure 11, where 3-D printing was used very successfully for patternmaking for sand moulds. From these moulds, several castings of automotive engine brackets were produced within the acceptable tolerance as prototypes for functional testing of the power train, before the final die castings were produced.

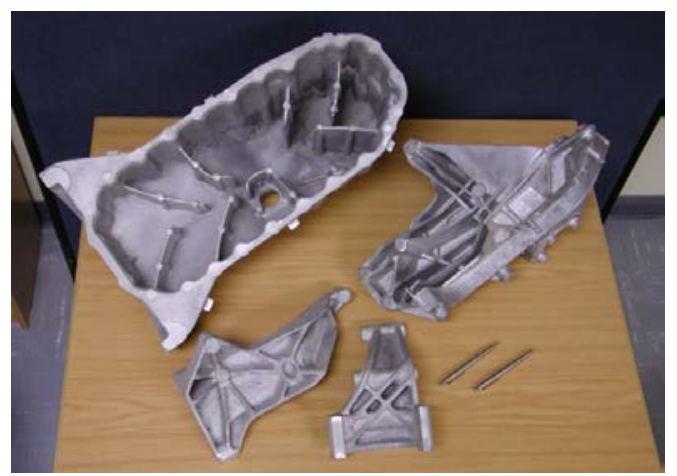

Figure 11: Sand cast prototypes of automotive engine brackets and oil sump for functional testing

\subsection{Medical field}

Since its initial application of being merely a visual aid for surgical planning, the use of 3-D printing in the medical field has grown significantly to include, among other things, patientspecific orthopaedic and craniofacial implants, guides for surgical procedures, scaffolds for tissue engineering, and drug delivery systems for pharmaceutical administration. Anatomical models (or medical models), however, remain the most commonly-used medical application of the 3-D printing process. These models are physical replicas of patients' hard- or soft-tissue anatomy. They help surgeons to improve their planning of complex surgical procedures, resulting in a reduction of surgical time and more predictable surgical outcomes (Figure 12) [9]. They are useful in the pre-bending of metallic reconstruction plates, creating patient-specific facial implants, and measuring and fitting devices used during other reconstructive surgeries. 


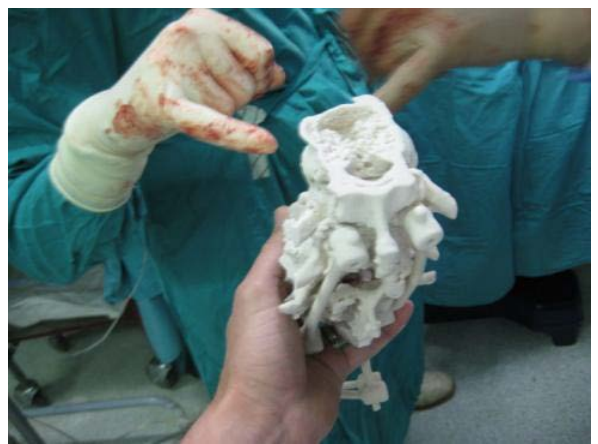

Figure 12: Medical model, used during revision surgery, that shows the spine and previous implants

\subsection{Architecture}

Another area where 3-D printing has been successfully applied is in producing architectural models for planning and visualisation. Once again, the capability to print in colour adds value to the final quality of architectural models. Unfortunately, the successful use of AM for this application currently relies on a very labour-intensive process to prepare CAD models for printing. Models of buildings, for example, cannot always be uniformly scaled so that they are small enough for the build volume of standard 3-D printers, without small features virtually disappearing. Wall thicknesses may become too thin or railings and window frames become too small. This then requires CAD models to be specially redesigned for the prototyping stage, which is unproductive and adds risk in the human translation of the original CAD data.

One solution to this problem is that CAD models are cut into smaller sections. These sections can then be built separately and assembled afterwards. Although some detail, such as the rails, had to be enlarged for this scaled model, the Millennium Tower in Durban, South Africa (Figure 13) is a good example of the intricate detail and complexity that can be achieved when using 3-D printing models for architectural visualisation. The model was built in 13 sections, not only because its large size exceeded the build envelope by far, but also to facilitate secondary operations such as de-powdering and infiltration.

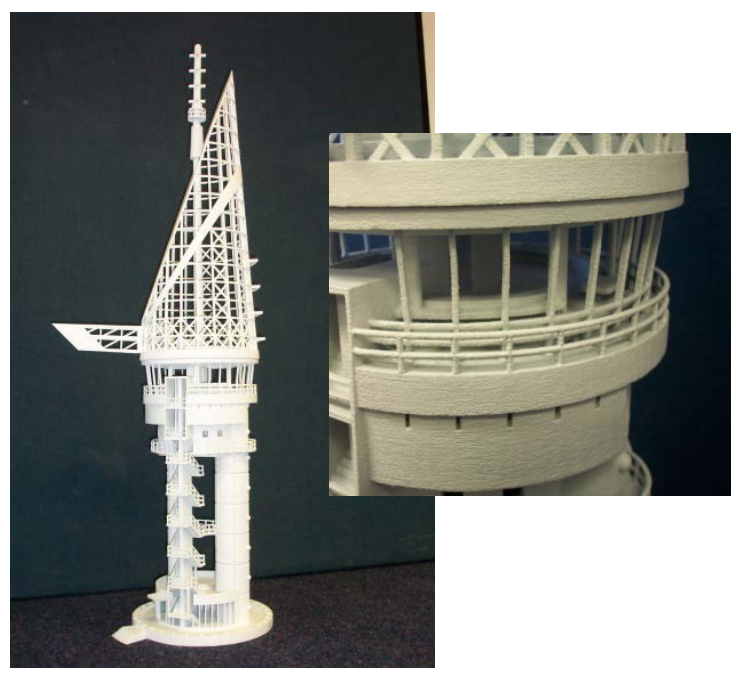

Figure 13: Model of the Millennium Tower in Durban, South Africa, built on a Z Corp 3-D printer 
Extensive market research shows that the 3-D printing process is the most widely-used AM method in the professional world, and above all, within the product development phase. While the 'continuous printing' technique, as used predominantly in the 'fused deposition modelling' process, is mostly responsible for the high sales numbers being focused on certain applications such as concept design and visualisation, the DoB version is characterised by a large variety of applications that include art, education, architecture, and the medical and industrial fields. Thus the question of continually updating the capability profile of this process is of paramount importance for current and potential users such as designers, educators, medical practitioners, manufacturing engineers, and architects.

This paper presents the results of recent studies that show how improvements in hardware can lead to improvements in material characteristics, software, and process performance as a whole, and can push application boundaries, quality, and efficiency. This paper highlights the influence level of certain factors on the system's capabilities, and illustrates the results from enhancing application areas. In this way, the opportunity potential for entrepreneurs and innovators stands wide open.

\section{REFERENCES}

[1] Wohlers, T. 2011. Additive manufacturing: State of the industry. Fort Collins.

[2] Dimitrov, D. \& de Beer, N. 2006. Developing capability profile for the three dimensional printing process. $R \& D$ J ournal, 22, pp. 17-25.

[3] J acobs, P. 1996. Stereolithography and other RP\&M technologies. New York: ASME Press.

[4] Dimitrov, D., van Wijck, W., Schreve, K. \& de Beer, N. 2006. Investigating the achievable accuracy of three dimensional printing. Rapid Prototyping J ournal, 12(1), pp. 42-52.

[5] Kim, G. \& Oh, Y. 2008. A benchmark study on rapid prototyping processes and machines: Quantitative comparisons of mechanical properties, accuracy, roughness, speed, and material cost. Proceedings of the Institution of Mechanical Engineers - Part B - Engineering Manufacture, 222, pp. 201-215.

[6] Xu, F., Wong. Y. \& Loh, H. 2001. Toward generic models for comparative evaluation and process selection in rapid prototyping and manufacturing. Journal of Manufacturing Systems, 19(5), pp. 283-296.

[7] Walters, P., Huson, D., Parraman, C. \& Stanić, M. 2009. 3D printing in colour: Technical evaluation and creative applications. Impact 6 International Printmaking Conference, Bristol, September 2009.

[8] Stanić, M. \& Lozo, B. 2010. Color and permanence issues in 3D ink-jet printing. Proceedings of the 33rd International Convention, MIPRO.

[9] Honiball, R. 2006. The application of 3D printing in reconstructive surgery. MScEng Thesis presented at the University of Stellenbosch, Stellenbosch. 